\title{
Peer Education and Sexual Risk Behavior Among Adolescents: Does Urban Status Matter?
}

\author{
Sri Sumaryani ${ }^{1,2 *}$, Sri Andini Widya Ningrum ${ }^{2}$, Titi Savitri Prihatiningsih ${ }^{3}$, Fitri Haryanti ${ }^{3}$, Agus Gunadi $^{4}$ \\ ${ }^{1}$ Department of Maternity Nursing, Faculty of Medicine, Public Health and Nursing, Universitas Gadjah Mada, Yogyakarta, \\ Indonesi; '2Department of Maternity Nursing, School of Nursing, Universitas Muhammadiyah Yogyakarta, Bantul, Indonesia; \\ ${ }^{3}$ Department of Pediatric and Maternity Nursing, Faculty of Medicine, Public Health and Nursing, Universitas Gadjah Mada, \\ Yogyakarta, Indonesia; ${ }^{4}$ Department of Clinical Epidemiology, Faculty of Public Health, Universitas Indonesia, Depok, Indonesia
}

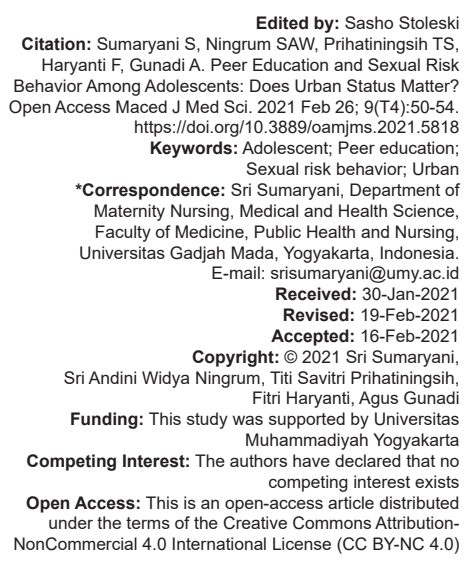

\section{Introduction}

More than 20,000 adolescents through Global School-Based Student Health Survey in 2015 conducted in Laos, Indonesia, Timor-Leste, and Thailand have shown a legit proportion of adolescents involved in various sexual risk behaviors [1]. Moreover, it was also reported that millions of. adolescents have encountered challenges on reproductive health and sexual activity, not limited to a high rate of unsafe abortion, contraception issues, and unintended pregnancy [2], [3]. The study also reported that almost $49.8 \%$ of adolescents had no idea about the use of birth control [1].

Risky sexual behavior is known as behavior carried out by adolescents consciously. Same sex or different sex of sexual desire was done without any consideration of any norms or applicable rules [4], [5]. Unfortunately, westernization much more influences Indonesian adolescents' reproductive health in the middle of cultural and social tradition, specifically its Islamic culture among society [6].

Having a population of more than 261 million people, Indonesia was also recorded as the fourth most populous country and the largest economy in Southeast Asia in the world [7]. The population rises in urban areas, with more than 65 million young people aged between 10 and 24 years old, representing $25 \%$ of the total population [8]. In Urban Area, Higher number of violence and crimes, sex workers, drugs, and economic and social status disparities happens in the environment's scope. It is also known where psychological stressors come with the diversity and density of the cities [9], [10]. In urban environments, it is usually easy to find places that sell alcoholic and smoke, which affect the risk for adolescents to engage in drugs and sexual risk behavior [3], [11], [12]. Nevertheless, a developing body of investigation proposes that neighborhood characteristics impact well-being results and behaviors, being counted as sexual behavior. The 
neighborhood characteristics, such as physical clutter, social disorganization, and concentrated destitution, have been linked to premarital sex, sexually transmitted diseases, and sexual organization designs among adolescents and young adults [13], [14].

Many adolescents, including high school students, are engaged in sexual risk behaviors, including HIV infection, leading to unintended pregnancies and sexually transmitted infections. Nationwide, 39.5\% of students had sexual intercourse, and $9.7 \%$ had sexual intercourse with four or more persons during their lives. About $46.2 \%$ of currently sexually active students indicated that during their last sexual encounter, either they or their partner had not used a condom or other contraceptive [11], [15].

In 2012, Indonesia's National Commission for Child Protection survey of more than 4000 adolescents in 12 regencies found that $97 \%$ had ever seen porn, $93.7 \%$ had kissed, oral sex, and petting, $62.7 \%$ had sexual intercourse among respondents who were junior high school students, and $21.2 \%$ of respondents who were high schools had an abortion [16].

It was recognized that the level of awareness of adolescent reproductive health among schoolchildren, such as teachers and peers, was necessary. As educational workers are closer to teenagers than their parents, school plays an essential role in addressing this health issue. Teachers and friends should serve as a guide for teenagers and provide them with knowledge about reproductive health. This study aims to assess the influence on teachers and peer awareness of adolescent reproductive health training [17]. Some studies have told teachers and peers that teaching on adolescent reproductive health should be carried out at any school to improve their awareness and skills and discourage adolescent sexual activity from being unsafe. Peers that significantly impact youth-based education will be more successful in making peer groups (peers). Peer group education has now become one of the popular strategies for developing health services in various regions, nations, and communities [17], [18]. This study aims to evaluate the effect of peer education on the prevention of adolescent activity at sexual risk in urban areas.

\section{Methods}

This research is a pre-experimental quantitative approach with a one-group pre-post-test model. The survey used in this study had 63 respondents. Samples were collected using a purposive sampling technique. The research was conducted in April at SMP Negeri $X$ Yogyakarta until June 2017. In this analysis, the independent variable was peer education, while the dependent variable was the prevention of sexual risk activity among adolescents.
There were 10 peer educators and 10 small groups, each of which consisted of seven respondents. The school or teacher chose the peer educator based on the criteria such as having the ability to lead the conversation and the ability to convey and obtain the information, having an interest in preventing sexual risk behavior, having empathy and no bias toward individuals engaging in sexual risk behavior, and having the ability to participate in the research process actively. Intervention implementation used peer-based learning, administered at each meeting over three sessions for a $1 \mathrm{~h}$ lesson (45 min). Education was carried out in small groups alongside each peer educator by discussion strategies focused on researchers' educational modules.

The instruments used were the researchers' prevention of sexual risk behavior questionnaire and were declared accurately at $r$ 0.295-0.748 and effectively with an alpha value of 0.890 . Sexual risk behavior prevention is considered successful if a score covers $75-100 \%, 50-74 \%$ is considered less, and $49 \%$ is considered adequate. Using the Wilcoxon sign-rank test, the data obtained were then analyzed.

\section{Results}

Based on Table 1 on the frequency distribution of respondent characteristics by age, it appeared that up to 45 students were mainly 13 -year-old teenagers (71.4\%). According to the data of gender characteristics, 32 students $(50.8 \%)$ were marginally dominated by female students, while more than half of the students $(50.8 \%)$ never received sexual education based on the experience of receiving sexual education.

Table 1: Distribution of respondents' characteristics

\begin{tabular}{lll}
\hline Char & $\mathrm{n}$ & $\%$ \\
\hline Age & & \\
12 years old & 13 & 20.6 \\
13 years old & 45 & 71.4 \\
14 years old & 3 & 4.8 \\
15 years old & 1 & 1.6 \\
16 years old & 1 & 1.6 \\
Gender & & \\
$\quad$ Male & 31 & 49.2 \\
Female & 32 & 50.8 \\
Receiving sexual education & & \\
Yes & 31 & 49.2 \\
No & 32 & 50.8 \\
Total & 63 & 100 \\
\hline
\end{tabular}

Prevention of sexual risk behaviors in urban areas by teenagers is shown in Table 2. Their ability to avoid sexual risk behavior in the good category increased from 49 students $(77.8 \%)$ to 52 students after gaining peer education on preventing adolescent sexual risk behavior (82.5\%).

The standard deviation was 0.065 based on Table 3; then, it decreased to 0.057 after the delivery of sexual education with a peer-based education approach. $p=0.086$ was more significant than 0.05 based on the 
Table 2: Distribution of the prevention of sexual risk behavior among adolescent before and after peer education

\begin{tabular}{|c|c|c|c|c|}
\hline \multirow[t]{2}{*}{ Category } & \multicolumn{2}{|c|}{ Before } & \multicolumn{2}{|c|}{ After } \\
\hline & $\mathrm{n}$ & $\%$ & $\mathrm{n}$ & $\%$ \\
\hline Good & 49 & 77.8 & 52 & 82.5 \\
\hline Moderate & 14 & 22.2 & 11 & 17.5 \\
\hline Low & 0 & 0 & 0 & 0 \\
\hline Total & 63 & 100 & 63 & 100 \\
\hline
\end{tabular}

Wilcoxon sign-rank test statistical test (0.05). Based on $p<0.05$ condition, It can be assumed that the prevention of sexual risk behavior among adolescents in urban areas before and after sexual education using peer education methods was not substantially different or that the use of peer education did not influence the prevention of sexual risk behavior in adolescents in urban areas in regard to sexual education.

Table 3: Comparison of the analysis of the findings

\begin{tabular}{llll}
\hline Group & Standard deviation & $n$ & $p$-value \\
\hline Pre-test & 0.065 & 3 & 0.086 \\
Post-test & 0.057 & 3 & \\
\hline
\end{tabular}

\section{Discussion}

Based on the frequency distribution of prevention of sexual risk behavior in adolescents in urban areas, prevention of sexual risk behavior before and after peer education in adolescents in urban areas is included in both categories, as shown in Table 2. Adolescents in urban areas are already in the Good Classification on Prevention of Sexual Risk Activity $(p=0.086)$, both before and after the intervention. Media may play an essential role in the prevention of sexual risk behavior of adolescents in urban areas, including widespread through the internet [19]. It has been found that media messages are interpreted to make a significant contribution to adolescent risk behavior intentions, especially in sexual activity [20], [21]. It was explained by the study by M'Imaita that easy access to information through the internet had given a significant impact. Teenagers will quickly note that pornographic images and text, apparel and fashion, sex styles, and contraceptive use have been included in teenage knowledge through the internet [19], [22]. The internet has become an essential source of unregulated sexual and pornographic material [19], [23]. In addition, research conducted among 153 students in the $1^{\text {st }}-3^{\text {rd }}$ grade for audiovisual influence among junior high school has shown that audiovisual media improved the understanding of sexual reproductive health among adolescents [24].

In addition, research involving 1990 teenagers aged 14-17 years old (50.3\% Caucasian, 49.7\% African, and $48.1 \%$ women) showed that susceptibility to media images of alcohol and sex combinations was positively associated with adolescent beliefs and attitudes [25]. Even with the widespread popularity of social media, television (TV) and film content remain a significant source of environmental influences.
According to national surveys of teenage media use, the time they spend with the media tends to be dominated by television. TV continues to dominate the time they spend with the media, according to national surveys of teen media use [26].

Other factors that may affect peer education provision to deter sexual risk behavior among adolescents in urban areas are ineffectiveness or have no impact $(p>0.05)$, such as the timing of ineffective education and noisy environment. The right and optimal time are fundamental to achieve educational success. As has been explained above, the body has certain times that are most effective for doing activities. For example, in terms of studying, the body will be more optimal in the morning because the hormones that affect concentration are at their peak. It is in line with the Islamic perspective that morning is a good time to learn and start activities. In a hadith, the Messenger of Allah showed concern for morning time and prayed: "O Allah, bless my people in the morning. "Rasulullahshollallahu" alaih wa sallam used to send sariyyah or war troops early in the morning, and Sakhru was a merchant; he used to deliver his trading caravans early in the morning so that he prospered and his wealth increased." (HR Abu Dawud 2239).

A Muslim cleric Khalil bin Ahmad also agreed; he said, "the time of the clearest mind is the time of dawn" (Wafayatul A'yan, 1/173). It shows that morning is a good time for education. However, the process of implementing education at the time of the intervention in urban areas was instead carried out during the day, during the last lesson time, where the concentration level has decreased. Thus, it affects the learning or educational outcomes.

The research environment in urban areas is in a traffic area, so the atmosphere is quite noisy. A noisy environment also influences education's ineffectiveness as a noisy atmosphere will disrupt concentration and impact poor learning outcomes [27]. Proof explaining that noisy environments can reduce learning achievement is based on the analysis of the questionnaire conducted in this study. About 96\% of students stated that the school was noisy, and $89 \%$ of respondents said that traffic noise interfered with their concentration in teaching and learning in the classroom. Furthermore, based on an analysis of student achievement in Grades 8 and 9, it had decreased by $62.5 \%$. Conversely, a quiet environment can improve concentration so that learning outcomes can be achieved optimally. Another study showed that the environment is an external factor that influences learning achievement, and a comfortable and calm classroom atmosphere can increase understanding of the material presented. Thus, based on the discussion above, it can be understood that providing peerreviewed education in the prevention of risky sexual behavior among adolescents in urban areas does not have a significant impact due to a number of factors, 
namely, the ineffective implementation of education time and the noisy environment [28], [29].

\section{Conclusion}

Based on the result of this study, it can be concluded that there was no significant impact on the reduction of adolescent sexual risk behaviors in urban areas through peer education. The media may significantly influence the prevention of sexual risk in urban adolescents. To prevent sexual risk behavior among adolescents in an urban environment, further research is recommended to identify the best intervention using more profound internal and external relevant variables and presenting media impact association study.

\section{Acknowledgments}

Generous support has come from Universitas Muhammadiyah Yogyakarta as the prominent supporter of the study. We would like to give our highest gratitude to the respondents and team who have a significant effort in the process of this study.

\section{References}

1. Peltzer K, Peltzer K, Pengpid S, Pengpid S. Sexual risk behaviour and its correlates among adolescents in Indonesia, Laos, Thailand and Timor-Leste: Results from national school surveys in 2015. Int J Adolesc Med Health. 2020;1. https://doi. org/10.1515/ijamh-2019-0230

PMid:32549165

2. Simak VF, Fitriyani $P$, Setiawan A. The relationships between risky sexual practices and spiritual intelligence of adolescents in Indonesia. Compr Child Adolesc Nurs. 2019;42(1):73-81. https://doi.org/10.1080/24694193.2019.1578298

PMid:31192724

3. Pedrana AE, Pina J, Padmawati RS, Zuhrina R, Lazuardi L, Lim MS, et al. A quasi-experimental text messaging trial to improve adolescent sexual and reproductive health and smoking knowledge in Indonesia. Sex Health. 2020;17(2):167-77. https:// doi.org/10.1071/sh18199

PMid:32017868

4. BKKBN. Survei Demografi dan Kesehatan: Kesehatan Reproduksi Remaja 2017, Badan Kependudukan dan Keluarga Berencana Nasional; 2018. p. 1-606. https://doi.org/10.31219/osf.io/eukbj

5. Deswinda D, Machmud R, Yusrawati $Y$, Indrapriyatna AS, Bayhakki B. Adolescent pregnancy prevention behavior in Indonesia: Internal and external factors influencing. Open Access Maced J Med Sci. 2020;8(E):516-20. https://doi. org/10.3889/oamjms.2020.4946

6. Susanto T, Rahmawati I, Wantiyah W. A community-based friendly health clinic: An initiative adolescent reproductive health project in the rural and urban areas of Indonesia. Int J Nurs Sci. 2016;3(4):371-8. https://doi.org/10.1016/j.ijnss.2016.11.006

7. World Bank, Indonesia Data; 2020. Available from: https://www. data.worldbank.org/country/id. [Last accessed on 2020 Nov 27].

8. Kementrian Kesehatan Republik Indonesia, Hasil Utama Riset Kesehatan Dasar (RISKESDAS) 2018; 2018.

9. Skinner SR, Marino J, Rosenthal SL, Cannon J. A prospective cohort study of childhood behaviour problems and adolescent sexual risk-taking: Gender matters. Sex Health. 2016;14(6):48. https://doi.org/10.1071/sh16240

10. Wallace SA, Neilands TB, Phillips KS. Neighborhood context, psychological outlook, and risk behaviors among urban African American youth. Cultur Divers Ethnic Minor Psychol. 2017;23(1):56-69. https://doi.org/10.1037/cdp0000108 PMid:27281486

11. Bonar EE, Walton MA, Epstein-Ngo QM, Zimmerman MA, Blow FC, Cunningham RM. Two-year trajectories of sexual risk behaviors among drug-using adolescents and emerging adults in an urban community. AIDS Behav. 2017;21(7):2069-78. https://doi.org/10.1007/s10461-016-1570-z PMid:27714523

12. Amoo E, Adekeye OA, Omumu F, Akinpelu OO, Ajayi MP, Olawande $\mathrm{T}$, et al. Drug use and high-risk sexual behavior among school-going adolescents in Nigeria. Open Access Maced J Med Sci. 2020;8(E):256-61. https://doi.org/10.3889/ oamjms.2020.3290

13. Frye V, Nandi V, Egan JE, Cerda M, Rundle A, Quinn JW, et al. Associations among neighborhood characteristics and sexual risk behavior among black and white MSM living in a major urban area. AIDS Behav. 2017;21(3):870-90. https://doi. org/10.1007/s10461-016-1596-2

PMid:27817101

14. Peshevska DJ, Raleva M, Filov I, Sethi D, Jordanova T, HazdiHamza K, et al. Association between physical abuse, physical neglect and health risk behaviours among young adolescents: Results from the national study. Open Access Maced J Med Sci. 2014;2(2):384-9. https://doi.org/10.3889/ oamjms.2014.066

15. Mathews C, Eggers SM, Townsend L, Aarø LE, de Vries PJ, Mason-Jones AJ, et al. "Effects of PREPARE, a multi-component, school-based HIV and intimate partner violence (IPV) prevention programme on adolescent sexual risk behaviour and IPV: Cluster randomised controlled trial. AIDS Behav. 2016;20(9):1821-40. https://doi.org/10.1007/s10461-016-1410-1

PMid:27142057

16. UNICEF, One is Too Many; 2016. p. 8-9.

17. Widyatuti W, Waluyanti FT, Mulyadi B, Nursasi AY. The influence of health training on teachers and students' knowledge of adolescent reproductive health. Enferm Clin. 2018;28(2):332-6. https://doi.org/10.1016/s1130-8621(18)30180-3 PMid:30115359

18. Halida EM, Andriani F, Septiriani D. Effect of Premarital Sex Education with Peer Method to Improving Youth Knowledge and Attitude about Premarital Sexual Behavior at Vocational School ' $X Y$ ' in Padang City, $1^{\text {st }}$ Annual Conference of Midwifery; 2017. p. 36-42. https://doi.org/10.2478/9788366675087-006

19. Dutt S, Manjula M. Sexual knowledge, attitude, behaviors and sources of influences in Urban college youth: A study from India. Indian J Soc Psychiatry. 2017;33(4):319. https://doi. org/10.4103/0971-9962.218602

20. Scull TM, Kupersmidt JB, Malik CV, Keefe EM. Examining the efficacy of an mHealth media literacy education program for sexual health promotion in older adolescents attending 
community college. J Am Coll Health. 2018;66(3):165-77. https://doi.org/10.1080/07448481.2017.1393822

\section{PMid:29068772}

21. Scull TM, Kupersmidt JB, Malik CV, Keefe EM. Adolescents media-related cognitions and substance use in the context of parental and peer influences tracy. Bone. 2010;23(1):1-7.

22. M'imaita JG. Influence of Mass Media on Adolescents' Expression of Sexuality and Sexual Behavior in Nairobi Province, Kenyatta University; 2005.

23. Maxwell KA. Friends: The role of peer influence across adolescent risk behaviors. J Youth Adolesc. 2002;31(4):267-77. https://doi.org/10.1023/a:1015493316865

24. Djannah SN, Sulistyawati S, Sukesi TW, Mulasari SA, Tentama F. Audio-visual media to improve sexual-reproduction health knowledge among adolescent. Int J Eval Res Educ. 2020;9(1):138-43. https://doi.org/10.11591/ijere.v9i1.20410

25. Bleakley A, Ellithorpe ME, Hennessy M, Khurana A, Jamieson P,
Weitz I. Alcohol, sex, and screens: Modeling media influence on adolescent alcohol and sex co-occurrence. J Sex Res. 2018;54(8):1026-37. https://doi.org/10.1080/00224499.2017.12 79585

PMid:28276932

26. Common Sense, The Common Sense Census: Media Uses by Tweens and Teens; 2012.

27. Zikri MR. Analysis of the impact of noise on communication and concentration of student learning on a busy road traffic. Journal of Wetland Environmental Technology. 2015;3(1):1-10. https:// doi.org/10.26418/jtllb.v3i1.11913

28. Eriksen W. Facing Puberty: Exploring the Onset, Symptoms and Experience of Menses in Females with Autism Spectrum Disorder; 2016. p. 1.

29. Ningrum SA, Sumaryani S. Peer education prevents sexual risk behavior among adolescents in rural area. Indones Nurs J Educ Clin. 2018;2(2):193. https://doi.org/10.24990/injec.v2i2.172 